УДК 631.4 (571.621)

\title{
ИЗМЕНЕНИЕ КОНЦЕНТРАЦИЙ ТЯЖЕЛЫХ МЕТАЛЛОВ ПОЧВ ЮГА СРЕДНЕАМУРСКОЙ НИЗМЕННОСТИ ПРИ ДЛИТЕЛЬНОМ СЕЛЬСКОХОЗЯЙСТВЕННОМ ИСПОЛЬЗОВАНИИ
}

\author{
Зубарев Виталий Александрович', \\ Zubarev_1986@mail.ru \\ Мищук Светлана Николаевна', \\ svetamic79@mail.ru \\ ' Институт комплексного анализа региональных проблем ДВО РАН,
Россия, 679016, г. Биробиджан, ул. Шолом-Алейхема, 4.
}

Актуальность исследования обусловлена необходимостью оценки экологического состояния мелиорируемых почв приграничных районов Среденеамурской низменности, арендуемых азиатскими рабочими, которые для получения высоких урожаев используют в больших объемах минеральные удобрения, стимуляторы роста и химикаты для защиты растений, что приводит к деградации сельскохозяйственных почв.

Цель: анализ изменений концентраций тяжелых металлов почв Среднеамурской низменности при длительном сельскохозяйственном использовании.

Объект: лугово-глеевые немелиорированные и мелиорированные почвы, используемые в сельскохозяйственном обороте.

Методы: метод атомно-абсорбционной спектрометрии на спектрометре "Solaar 6М» и расчет суммарных коэффициентов загрязнения почв.

Результаты. Проведенное исследование показало, что на изменение концентраций тяжелых металлов почв Среднеамурской низменности при длительном сельскохозяйственном использовании могло оказывать влияние атмосферное увлажнение летнеосеннего периода. Показано, что в мелиорированных почвах к окончанию сельскохозяйственного сезона наблюдается снижение содержания тяжелых металлов и уменьшение суммарного коэффициента загрязнения, в то время как в неосушенных почвах противоположный процесс - увеличение загрязнения. Исследовано влияние степени затопления пойм на содержание гумуса и кислотность почв, которые определяют миграцию и формирование концентрационных рядов тяжелых металлов. В засушливые годы концентрации металлов практически не изменялись, в период наводнения (2013-2014 гг.), при обильном выпадении осадков преобладали процессы, ведущие к увеличению концентраций цинка, свинца и меди. Затопление почв изменяло содержание тяжелых металлов вследствие механического стока, уменьшения содержания гумуса и изменения кислотности почв.

\section{Ключевые слова:}

Среднеамурская низменность, лугово-глеевые почвы, тяжелые металлы, приграничный район, осушительная мелиорация.

\section{Введение}

Повышение урожайности сельскохозяйственных культур на современном этапе развития земледелия связано с систематическим внесением минеральных удобрений. Вместе с тем удобрения не только обеспечивают высокую продуктивность земледелия, но могут оказывать и негативное воздействие на почву из-за содержащихся в них примесей, в том числе тяжелых металлов ${ }^{\text {тм }}$. Их источником являются минеральные удобрения, пестициды, известковые материалы, орошение сточными водами. Накапливаясь в почве в опасных концентрациях, они негативно влияют на жизнедеятельность почвенной биоты, загрязняют сельскохозяйственную продукцию [1-4].

Интерес к подобным исследованиям вызван территориальной близостью Китая к южной части Среднеамурской низменности, что предопределяет сходство почвенно-климатических, генетических, и в какой-то мере экономических условий сельскохозяйственного производства. $K$ тому же в последние годы увеличиваются масштабы использования пахотных почв юга Среднеамурской низменности китайскими арендаторами, применяющими технологии, для которых характерно интенсивное использование минеральных удобрений и пестицидов. Контроль состояния арендуемых земель по ря- ду причин практически отсутствует. Использованные после аренды участки часто забрасывают, пытаясь получить взамен другие участки с менее деградированными почвами. Подобная ситуация складывается не только на Дальнем Востоке, но и в других регионах России, граничащих с Китаем (Забайкалье, Восточной Сибири) [5].

Для прогноза деградации почвенного покрова важно наблюдать за изменением физических и химических свойств почвы в условиях интенсивного применения высоких доз удобрений, ядохимикатов и пестицидов, как это практикуется в современной земледельческой практике Китая [6]. Агрохимическая практика китайских производителей, сложившаяся за последние десятилетия, свидетельствует о том, что при выращивании сельскохозяйственных культур используется большое количество минеральных удобрений, пестицидов и других средств химизации. Например, в начале 2000-х гг. в провинции Хэйлунцзян среднее количество внесенных минеральных удобрений составляло 130 кг/га, в Приморском крае - 6,0 кг/га, в Амурской область - 6,4 кг/га, в ЕАО - 1,5 кг/га [7].

Целью работы является анализ изменений концентраций тяжелых металлов в лугово-глеевых почвах Среднеамурской низменности при длительном сельскохозяйственном использовании. 


\section{Материалы и методики исследования}

Среднеамурская низменность - обширная аккумулятивная равнина в системе нижнеамурских низменностей, является частью трансграничной Сунгари-Среднеамурской физико-географической провинции, на российскую часть которой приходится 59,7 \% ее площади, китайскую-40,3\% [8].

Среднеамурская низменность (рис. 1) расположена в зоне хвойно-широко-лиственных лесов, представляет собой озерно-аллювиальную равнину, сложенную рыхлыми отложениями среднего и верхнего плейстоцена. Она относится к Тихоокеанской климатической области умеренного пояса и характеризуется континентальным климатом с муссонными чертами. Среднегодовая сумма атмосферных осадков составляет 500-600 мм, в отдельные годы до 1000 мм. Сумма температур выше $10{ }^{\circ} \mathrm{C}-2200-2400{ }^{\circ} \mathrm{C}[9]$.

Складывающиеся природно-климатические условия - избыточное поверхностное увлажнение, тяжелый гранулометрический состав почв и почвообразующих пород, неустойчивая верховодка, фиксируемая сезонной мерзлотой, и пульсирующий окислительно-восстановительный режим определяют процессы формирования почв и их специфические черты: отбеливание подгумусовых горизонтов, конкреции и глееобразование, дифференциацию профиля по элювиально-иллювиальному типу.

По механическому составу большинство почв относится к тяжелым и средним суглинкам. Гранулометрический состав почв средне- и тяжелосуглинистый. Плотность сложения пахотного горизонта колеблется в пределах 0,9-1,18 г/ $\mathrm{cm}^{3}$, подпахотного $1,4-1,5$ г/см${ }^{3}$. Для профиля этих почв характерна четко выраженная структура. Водоустойчивость почвенных агрегатов в пахотном слое высокая и составляет 80-90\%, в иллювиальном горизонте она неустойчива и варьирует в пределах 10-75\%. Тяжелый гранулометрический состав почв является основной причиной их переувлажнения при обильном выпадении летних осадков. Это ухудшает условия питания растений и затрудняет проведение агротехнических работ [10].

Для изучения влияния осушительной мелиорации на состояние почв на территории Среднеамурской низменности полевые исследования проводились с 2009 по 2014 гг. Для сравнительного анализа выбраны немелиорированные и мелиорированные используемые в сельскохозяйственном обороте (рис. 2) лугово-глеевые почвы первой надпойменной террасы речной долины р. Амур. В каждом исследуемом полигоне производился отбор проб из поверхностного почвенного горизонта (0-20 см) методом квадрата по ГОСТ 28168-89 [11]. Общее число всех проб за исследуемый период - 340 (170 образцов почв немелиорированных и 170 мелиорированных).

В лабораторных условиях все образцы почв были высушены до воздушно-сухого состояния и подвержены измельчению в планетарной мельнице «Pulverisette 6» фирмы «FRITCH» до пылевидной фракции $<0,25$ мкм.

В подготовленных образцах почв проводили определение подвижных форм ТМ. экстрагировали $1 \mathrm{H} . \mathrm{HNO}_{3}$ (осч), поскольку с помощью этого экстрагента выявляется фонд ТМ, способный стать подвижным в системе почва - сельскохозяйственная культура [12]. Из группы ТМ определялись: железо (Fe), марганец ( $\mathrm{Mn})$ - типичные природные элементы Буреинской ландшафтно-геохимической провинции; медь $(\mathrm{Cu})$, свинец $(\mathrm{Pb})$, цинк (Zn) - характерные природно-антропогенные загрязнители данной территории.

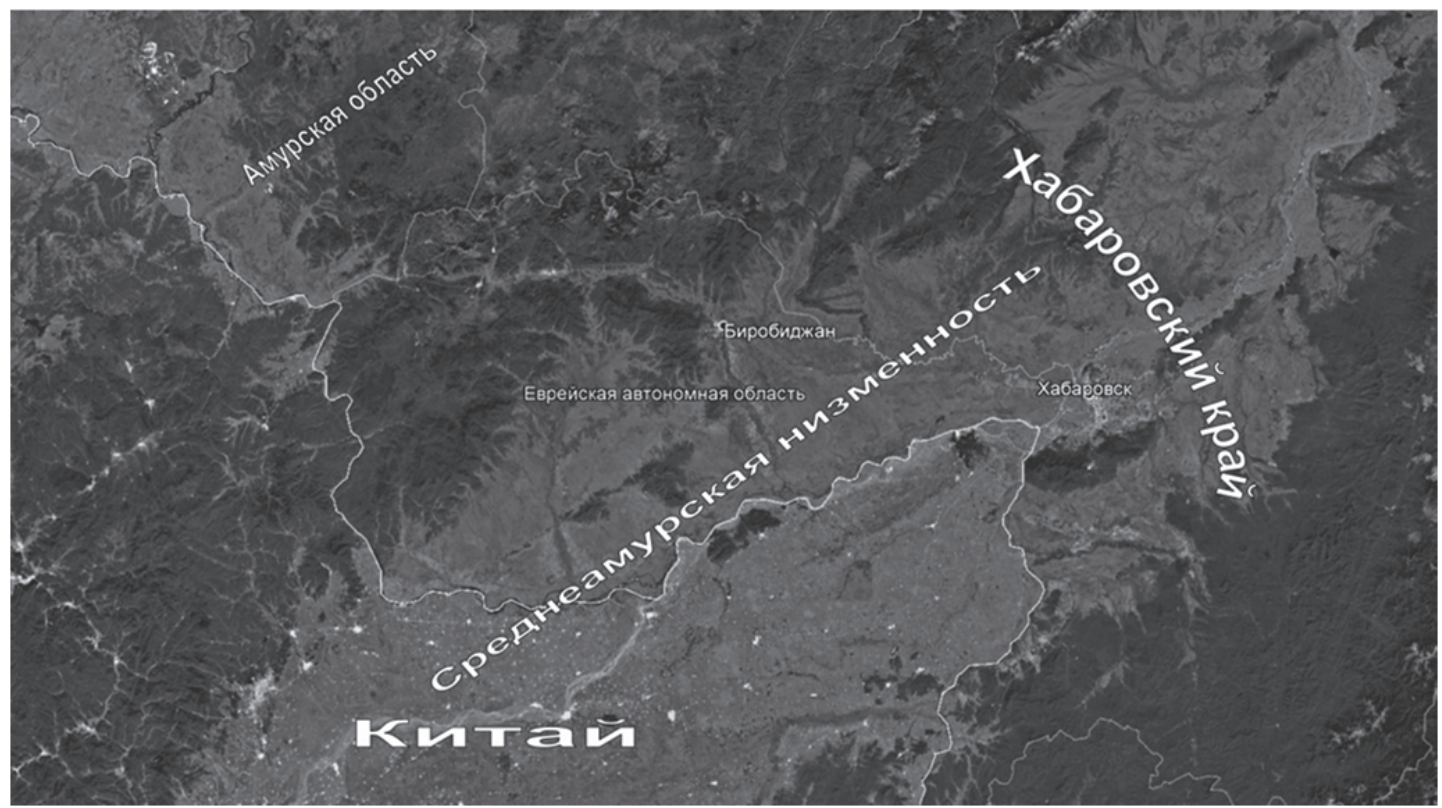

Puс. 1. Среднеамурская низменность

Fig. 1. Middle Amur Lowland 


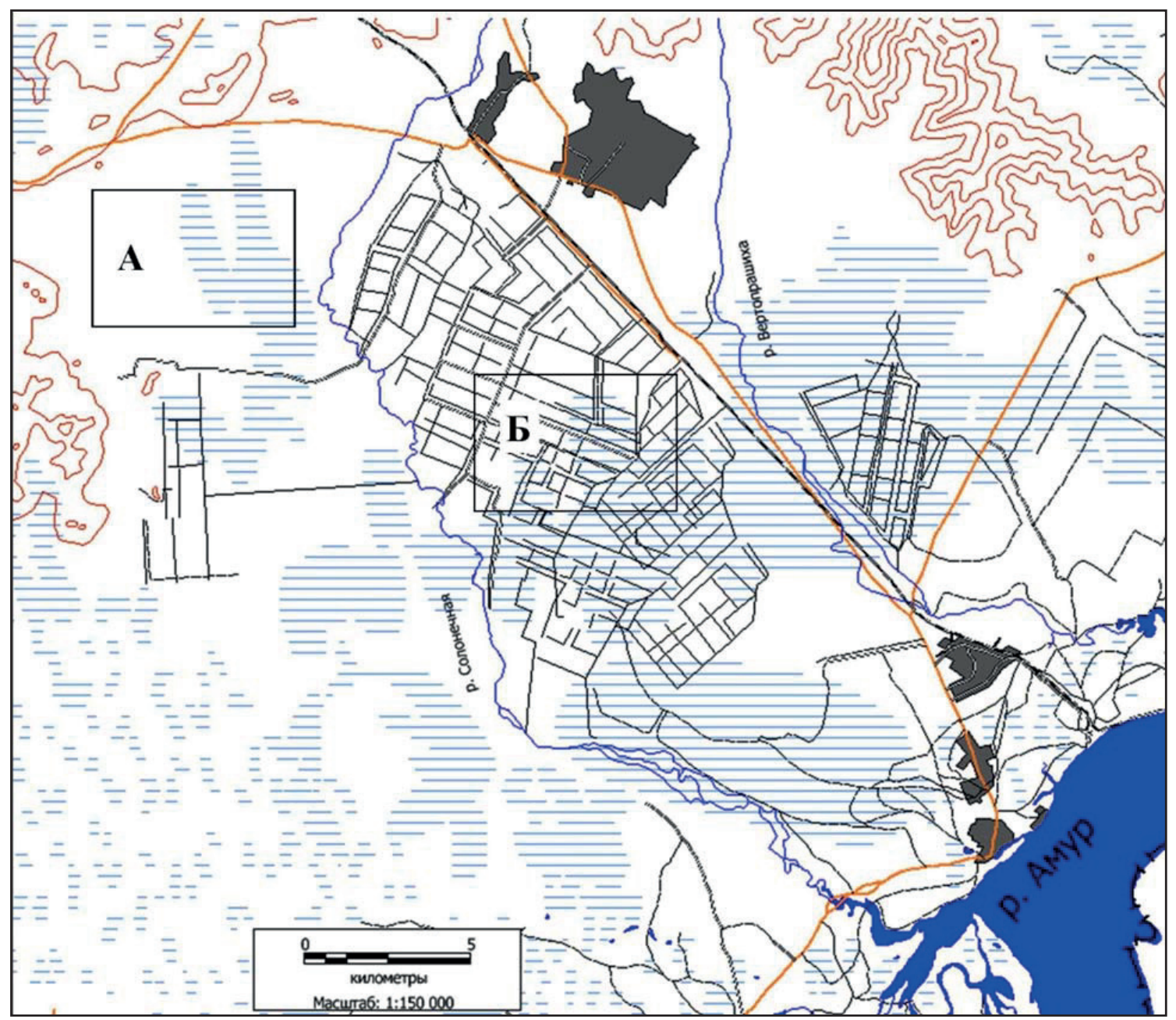

Pис. 2. ППолигоны отбора проб почв: $A$ - немелиорированные, Б-лелиорированные почвы

Fig. 2. Land sampling ranges: $A$ - not reclaimed soil, $B$ - reclaimed soils

Содержание ТМ анализировали методом атомно-абсорбционной спектрометрии (АAC) на прибоpe «ThermoElectron SOLAAR 6M» - это двулучевой, полностью автоматический спектрометр с двумя фиксированными атомизаторами - пламя (ацетилен воздух) и графитовая печь (аргон воздух), основанный на оптической схеме Эшелле с оптикой Стокдейла, полной термокомпенсацией и высокой светосилой, с дейтериевым корректором фона «Quadline» и «Зееман». Диапазон абсорбции от 0,150 до 3,000 А. Оптический диапазон 180-900 нм, автоматическая установка длины волны, напряжения на фотоумножителе и полосы пропускания $0,2,0,5,1,0$ нм с дополнительной 0,1 нм для длин волн меньше 400 нм. Спектрометр измеряет концентрацию каждого металла на характерной для него спектральной линии. Управление процессом измерения и обработка полученной информации производится в трехкратной повторяемости с помощью компьютера методом градировочного графика с автоматическим расчетом доверительного интервала [13].
Содержание гумуса определяли методом И.В. Тюрина [14], актуальную кислотность потенциометрией [15].

Все анализы проводили в 3-кратной повторности. Статистическую обработку - в программе «Microsoft Office Excel 2007». В работе приведены средние значения.

Все лабораторные исследования проводили на аппаратурной базе ИКАРП ДВО РАН, аналитик В.А. Зубарев.

Для комплексного анализа содержания ТМ в почвах были рассчитаны суммарные коэффициенты загрязнения $\left(Z_{\text {сг }}\right)$ с учетом индексов опасности поллютантов:

$$
Z_{\text {ст }}=\sum_{i=1}^{n}\left(K_{\mathrm{c}} \cdot K_{\mathrm{T}}\right)-(n-1),
$$

где $K_{\mathrm{c}}$ - коэффициент загрязнения почв, равный $K_{\mathrm{c}}=C_{i} / C_{\phi}$, где $C_{i}-$ фактическая концентрация элемента; $C_{\phi}$ - фоновое значение элемента; $K_{\text {т }}$ - индекс класса опасности поллютантов, равный 1,5 для элементов первого (Zn и $\mathrm{Pb}), 1$ - для второ- 
го $(\mathrm{Cu}, \mathrm{Fe}$,$) и 0,5$ - для третьего $(\mathrm{Mn})$ класса опасности, $n$ - количество ТМ [16]. В качестве $C_{\phi}$ применялись значения предельно допустимых концентраций (ПДК) подвижных форм ТМ в почвах.

\section{Результаты и их обсуждение}

По мнению ряда ученых, огромная роль в процессах формирования количественного содержания тяжелых металлов в почвах принадлежит генезису, распределению тяжелых металлов в горных породах и породообразующих минералах и различием состава и сложения материнской породы [17]. Вследствие изменения микрорельефа при проведении осушительной мелиорации в пределах водосборной территории изменяется вынос тяжелых металлов из поверхности почвенного горизонта по дренажным каналам в поверхностные водотоки. При этом значительную роль имеет атмосферное увлажнение, определяющее объем воды для поверхностного и подземного транзита загрязняющих веществ [18].

Как видно из данных, приведенных в таблице, во всех почвах содержание ТМ различно, оно детерминируется, вероятно, особенностью рельефа, интенсивностью поверхностного и подземного стоков в различные временные периоды, а также свойствами самого элемента.

Железо. Железо относится к числу сидерофильных элементов (типичных металлов для ЕАО), имеющих химическое сродство с углеродом (карбонаты), фосфором (фосфаты), серой (сульфаты, сульфиды) и кремнием (силикаты). В почвах железо не считается элементом-загрязнителем, и поэтому нормативов, лимитирующих его содержание в данной среде, не существует. Кларк железа в почве составляет 38000 мг/кг [19]. Железо является одним из основных элементов, входящих в состав почвы, колебание содержания железа в мелиорируемых почвах весьма существенно. В исследуемых образцах, не подверженных влиянию осушения, железо общее примерно на 80 \% находится в виде двухвалентного (закислого) железа и $20 \%$ приходится на трехвалентное (окислое) железо.
Повышенное количество $\mathrm{Fe}^{2+}$ связано с глеевыми процессами, зависящих от многообразных факторов, к которым можно отнести условия влажности исследуемой территории, гранулометрический состав почв, химические и биологические процессы, а также содержание и формы органического вещества и др. [20]. В противоположность этому при дренировании осушительными каналами создаются условия улучшенной аэрации, снижения влажности и изменения $\mathrm{pH}$ в строну нейтральной среды, что приводит к увеличению трехвалентного железа до $40 \%$.

Марганеи. Одним из наиболее необходимых для растений микроэлементов является марганец. Значительная аккумуляция марганца (Mn) в верхних горизонтах почв связана с фиксацией этого элемента гумусовыми веществами [21]. На осушительных системах концентрации марганца снижаются, возможно, это связано с изменением рН среды, при известковании, которое создавало условия для мощного развития корневой системы растений, снижения кислотности почв и развития более благоприятных для растений агрофизических свойств. Некоторые исследователи предполагают, что накопление марганца в сельскохозяйственной почве можно рассматривать как фактор, способствующий закреплению опасных тяжелых элементов. Количество марганца в почве зависит от ряда условий (уровня увлажнения, типа растительности, типов и доз вносимых удобрений, реакции почвенной среды). Наиболее существенное влияние на подвижность элемента оказывает известкование [22].

Цинк. Цинк в тяжелых по гранулометрическому составу глинистых почвах становится практически недоступным, в значительной степени Zn закрепляется гидроксидами железа. Максимальное содержание цинка наблюдалось в 2013-2014 гг. - 95,5 мг/кг, на осушительных системах. Именно в это время отмечалось максимальное количество выпавших атмосферных осадков - более 900 мм, то есть примерно в 3,5 раза выше месячной нормы. Одной из возможных причин увеличения содержания цинка в почвах является его высвобождение из фосфатных и калийных

таблица. Концентрации тяжелых металлов в лугово-глеевых почвах Среднеамурской низменности в 2009-2014 г2.

Table. $\quad$ Concentrations of heavy metals in the soils of the Middle Amur Lowland in 2009-2014

\begin{tabular}{|c|c|c|c|c|c|c|c|}
\hline Название элемента/Item name & Полигоны отбора проб почв/Land sampling polygons & 2009 & 2010 & 2011 & 2012 & 2013 & 2014 \\
\hline \multirow{2}{*}{$\mathrm{Fe}_{\text {общ }}, \mathrm{мг} / \mathrm{kг}(\mathrm{mg} / \mathrm{kg})$} & мелиорированные/reclaimed soil & 3273,98 & 3276,07 & 3275,27 & 3263,25 & 3234,3 & 3278,71 \\
\hline & немелиорированные/not reclaimed soil & 3484,11 & 3514,67 & 3544,52 & 3525,03 & 3536,97 & 3478,89 \\
\hline \multirow{2}{*}{$\mathrm{Mn}^{2+}, \mathrm{мг} / \mathrm{кг}(\mathrm{mg} / \mathrm{kg})$} & мелиорированные/reclaimed soil & 90,61 & 88,67 & 90,65 & 91,36 & 88,44 & 85,46 \\
\hline & немелиорированные/not reclaimed soil & 107,5 & 108,15 & 107,83 & 108,12 & 108,81 & 109,01 \\
\hline \multirow{2}{*}{$\mathrm{Zn}^{2+}$, мг/кг $(\mathrm{mg} / \mathrm{kg})$} & мелиорированные/reclaimed soil & 6,7 & 6,61 & 6,53 & 6,48 & 10,12 & 9,21 \\
\hline & немелиорированные/not reclaimed soil & 8,15 & 8,03 & 8,57 & 8,27 & 8,39 & 8,4 \\
\hline \multirow{2}{*}{$\mathrm{Pb}^{2+}, \mathrm{мг} / \mathrm{к} \Gamma(\mathrm{mg} / \mathrm{kg})$} & мелиорированные/reclaimed soil & 2,01 & 2,07 & 2,08 & 2,01 & 5,71 & 5,85 \\
\hline & немелиорированные/not reclaimed soil & 6,67 & 6,8 & 6,81 & 6,91 & 6,7 & 6,85 \\
\hline \multirow{2}{*}{$\mathrm{Cu}^{2+}, \mathrm{мг} / \mathrm{\kappa} \Gamma(\mathrm{mg} / \mathrm{kg})$} & мелиорированные/reclaimed soil & 1,9 & 1,89 & 1,91 & 1,92 & 3,78 & 3,76 \\
\hline & немелиорированные/not reclaimed soil & 2,06 & 2,08 & 2,07 & 2,06 & 2,07 & 2,05 \\
\hline \multirow{2}{*}{$\mathrm{pH}_{\mathrm{KCl}}$, ед. (units) } & мелиорированные/reclaimed soil & 5,40 & 5,14 & 5,21 & 5,40 & 6,40 & 6,50 \\
\hline & немелиорированные/not reclaimed soil & 4,60 & 4,52 & 4,54 & 4,60 & 5,40 & 5,50 \\
\hline \multirow{2}{*}{ Гумус/Humus, \% } & мелиорированные/reclaimed soil & 4,87 & 4,04 & 4,48 & 4,63 & 3,25 & 3,16 \\
\hline & немелиорированные/not reclaimed soil & 3,64 & 3,52 & 3,37 & 3,26 & 3,46 & 3,38 \\
\hline
\end{tabular}


удобрений вследствие изменения $\mathrm{pH}$ среды в период катастрофического наводнения. С гумусом этот элемент образует устойчивые соединения. Адсорбция цинка почвой зависит от $\mathrm{pH}$. В щелочной среде цинк адсорбируется по механизму хемосорбции, а в кислой среде происходит катионо-обменное поглощение. При повышенной кислотности возрастает доля подвижного цинка [23]. Наиболее полно цинк адсорбируется оксидами железа. В наших исследованиях была установлена корреляционная зависимость $(r=0,7)$ между содержанием подвижных форм цинка в пахотном горизонте и изменением величины $\mathrm{pH}$ среды для почв. Цинк достаточно надежно закрепляется в почвах тяжелого гранулометрического состава.

Свинец. Свинец в ландшафте преимущественно мигрирует в бикарбонатной форме, а также в органических комплексах. Естественное содержание свинца в почве наследуется от материнских пород. Однако из-за загрязнения свинцом большинство почв, по-видимому, обогащено этим элементом, особенно их поверхностные почвенные горизонты - 0-20 см. В литературе имеется большое число данных о содержании свинца в почве, однако иногда трудно отделить данные, характеризующие немелиорированные уровни свинца в почвах, от данных, связанных с загрязнением поверхностного слоя почв. По данным наших исследований концентрация свинца в неосушенных почвах находится в пределах 2-3 мг/кг. Свинец легко адсорбируется глинистыми почвами, поэтому набольшие значения в неосушенных почвах 6-9 мг/кг. В почвах, отобранных в районах осушительной мелиорации, прослеживается снижение концентраций свинца во всех точках, однако в период промывного типа водного режима 2013-2014 гг. наблюдалась некоторая подвижность свинца вследствие выпадения большого количества атмосферных осадков, была установлена корреляционная зависимость $(r=0,62)$ между содержанием свинца в пахотном горизонте и изменением величины $\mathrm{pH}$ среды, а также $(r=0,7)$ объемом выпавших атмосферных осадков для почв, подверженных влиянию мелиорирования.

$M e \partial b$. Медь представляет собой один из наименее подвижных в почве микроэлементов. Ее подвижность в почве и доступность растениям во многом зависят от процессов адсорбции и комплексообразования. Основными источниками поступления соединений меди в почвы является использование фунгицидов (хлорокись меди, медный купорос, бордоская жидкость и др.) в сельскохозяйственном производстве [24]. На осушительных системах концентрации меди по сравнению с неосушенными снижаются. Наибольшие концентрации меди обнаружены в период катастрофического наводнения 2013 г. В почвах, подверженных влиянию мелиорирования, была установлена прямая корреляционная зависимость $(r=0,73)$ между содержанием меди в пахотном горизонте и изменением величины $\mathrm{pH}$ среды.
Поскольку сельскохозяйственные осушительные мелиорации предназначены для улучшения водного режима на заболоченных и переувлажненных землях, нами также рассмотрено влияние мелиорации на одни из основных характеристик почвенного плодородия - это гумус и кислотность почв [25]. Содержание гумуса является одним из основных показателей плодородия почв. Нами показано, что поверхностные плодородные горизонты немелиорированных почв (0-20 cм) содержали больше гумуса, чем мелиорированные. Осушительная мелиорация создает условия для достаточного, а в некоторые годы и избыточного увлажнения, что влияет на относительно высокую скорость гумификации и трансформации почвенного органического вещества. Всё это стало причиной формирования почв с относительно мощным гумусово-аккумулятивным горизонтом, а также повышенного содержания органического вещества почве. Повышение содержания гумуса в почве приводит к ускорению миграции железа, так как оно находилось в почвах в виде аморфных окисных и закисных, а также железо-гумусовых соединений. Аналогичные процессы происходили с подвижными соединениями марганца, потому что его миграция в верхних горизонтах почв также была связана с абсорбцией с гумусовыми веществами. Для меди и свинца существует обратная зависимость: их количество снижается при увеличении гумуса, поэтому прослеживается небольшое уменьшение концентраций данных ТМ. Таким образом, гумус может препятствовать миграции некоторых ТМ вследствие высоких сорбционных свойств, поскольку образовывает с ними сложные и комплексные соединения, менее доступные растениям [26].

Еще одним из факторов, обуславливающих подвижность ТМ, является кислотность почв [27]. В неосушенных почвах кислотность относится к категории кислые и слабокислые, при мелиорировании и прокладке дренажа изменяются кислородные условия почв, а также при сельскохозяйственном использовании этих земель вносятся различные удобрения и раскислители, приводящие к изменению кислотности почв в более нейтральную сторону. При этом при наводнении, приводящем к полному затоплению, происходит смыв с мелиорированных почв внесенных удобрений и, как следствие, снижение значений $\mathrm{pH}$. Во всех исследуемых образцах этот показатель в немелиорированных почвах меняется в интервале 4,1-4,9 ед. $\mathrm{pH}$, на осушительных системах - от 4,5 до 6,4 ед. $\mathrm{pH}$. Известно, что по отношению к кислотности цинк и медь являются подвижными элементами. Эти элементы быстро теряют подвижность в почве в результате химических реакций, сопровождающихся образованием труднорастворимых фосфатов, сульфатов, карбонатов, хроматов, молибдатов, гидрооксидов, а также за счет поглощения органическими и минеральными коллоидами [28].

Суммарные коэффициенты загрязнения почв также зависели от объема атмосферных осадков (рис. 3). 


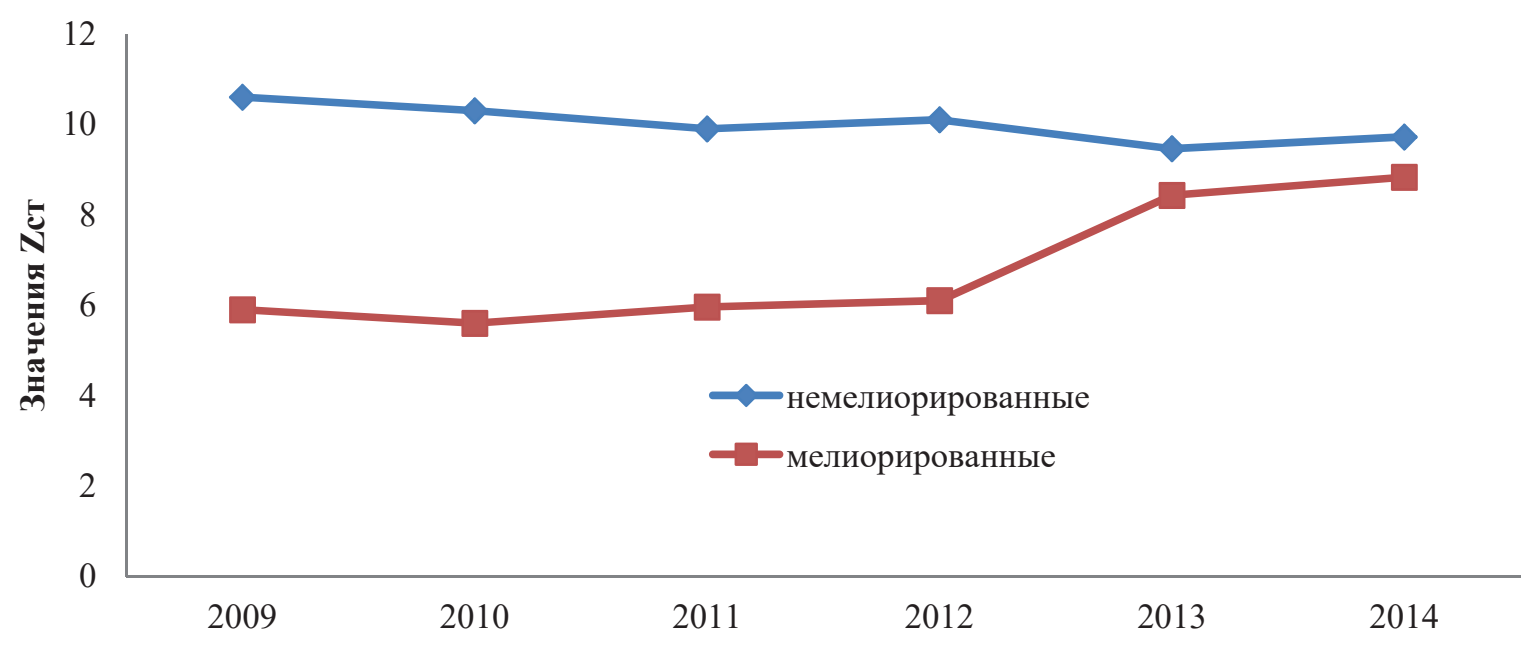

Рис. 3. Сумларные коэффициенты загрязнения неосушенных и осушенных лугово-глинистых почв

Fig. 3. Total contamination factors for not reclaimed and drained meadow-clay soils

Как видно из данных, приведенных на рис. 3, осушительная мелиорация положительно влияет на состояние почв, приводит к снижению концентраций TM. По величине $Z_{\text {сг }}$ немелиорированные почвы имеют наибольшие коэффициенты, при мелиорировании (осушительная система) эти значения снижаются, при этом по шкале $Z_{\text {ст }}$ все исследуемые образцы почв относятся ко второй категории качества - «среднее». Катастрофическое выпадение осадков в 2013-2014 гг. и последующее за ним затопление должно было привести к увеличению смыва ТМ из почв. Однако прослеживается накопление ТМ в почвах, которое может быть связано с разнообразными вторичными процессами в них, например, с изменением подвижности комплексов металлов, вертикальным переносом из нижних горизонтов и т. д. В итоге значения $Z_{\text {сг }}$ в мелиорированных почвах увеличились примерно в 1,5 раза (рис. 3) - однако категория качества почв осталась на прежнем уровне.

\section{Заключение}

В ходе работы был установлено, что осушительная сельскохозяйственная мелиорация положительно влияет на состояние почв, приводит к снижению концентраций ТМ. По величине суммарного коэффициента загрязнения почв $\left(Z_{\text {сг }}\right)$ не-

\section{СПИСОК ЛИТЕРАТУРЫ}

1. Конарбаева Г.А., Якименко В.Н. Эколого-агрохимическая оценка содержания тяжелых металлов в почве и растениях агрозенозов // Проблемы агрохимии и экологии. - 2017. № 1. - C. 16-21.

2. Zubarev V. A., Kogan R. M. Ecological Conditions of Watercourses in the Middle Amur Lowland in the Areas of Drainage Reclamation. Water Resources. - 2017. - V. 44. - № 7. - P. 940-951. URL: http://doi.org/10.1134/S0097807817070144 (дата обращения 25.01.2019).

3. Зубарев В.А. Территориальное изменение содержания биогенных элементов в почвах Среднеамурской низменности мелиорированные почвы имеют наибольшие коэффициенты, при мелиорировании (осушительная система) эти значения снижаются, при этом по шкале $Z_{\text {сг }}$ все исследуемые образцы почв относятся ко второй категории качества - «среднее». Под влиянием осушения происходит изменение кислотности почв в нейтральную сторону и увеличение гумуса почв, что может привести к переходу некоторых ТМ из легкорастворимых в труднорастворимые формы. В период наводнения (2013-2104 гг.) в мелиорированных почвах прослеживается увеличение концентраций цинка, свинца и меди, данные элементы входят в состав некоторых ядохимикатов и пестицидов. Затопление привело к изменению содержания тяжелых металлов вследствие механического стока, уменьшению содержания гумуса и изменения кислотности почв.

Таким образом, проведенные исследования показывают, что осушенные почвы содержат меньшие концентрации тяжелых металлов, которые могут мигрировать с системе почва-растение-человек, и с этой точки зрения их лучше использовать в сельскохозяйственном севообороте, чем не мелиорированные почвы.

Исследование выполнено при финансовой поддержке РФФИ в ралках научного проекта № 17-32-01100-ОГН.

(1976-1991 гг.) // Региональные проблемы. - 2014. - Т. 17. № 1. - C. 54-57.

4. Зубарев В.А. Агрохимическая оценка пахотных земель Еврейской автономной области за период 1963-1992 гг. // Региональные проблемы. - 2017. - Т. 20. - № 3. - С. 68-73.

5. Мищук С.Н. Российско-китайское сотрудничество в сельском хозяйстве Дальнего Востока России // Известия Российской академии наук. Серия географическая. - 2016. - № 1. - С. 38-48. URL: https://doi.org/10.15356/0373-2444-2016-1-38-48 (дата обращения 25.01.2019).

6. Мищук С.Н., Комарова Т.М., Мошков А.В. Трансформация территориальной структуры хозяйства Еврейской автономной 
области в пореформенный период // Региональные проблемы. - 2017. - Т. 20. - № 2. - С. 57-64.

7. Бурдуковский М.Л., Голов В.И., Ковшик И.Г. Изменение агрохимических свойств основных пахотных почв юга Дальнего Востока при длительном сельскохозяйственном использовании // Почвоведение. - 2016. - № 10. - С. 1244-1250. DOI: $10.7868 / \mathrm{S} 0032180 \mathrm{X} 16100051$

8. Фетисов Д.М., Климина Е.М. Антропогенная трансформация геосистем Среднеамурской низменности: ретроспективный анализ // Региональные проблемы. - 2015. - Т. 18. - № 4. C. $60-65$.

9. Аношкин А.В. Развитие пойменно-русловых комплексов рек территории Еврейской автономной области в условиях экстремальных паводков и повышенной водности // Региональные проблемы. - 2015. - Т. 18. - № 1. - С. 35-42.

10. Росликова В.И. Почвы Средне-Амурской низменности и их особенности агрогенных трансформаций // Вестник Тихоокеанского государственного университета. - 2009. - № 2 (13). C. $95-102$.

11. ГОСТ 28168-89. Почвы. Отбор проб. - М.: Стандартинформ. 2008. -7 c.

12. Матюшкина Л.А. Проблемы и принципы эколого-агрохимической оценки состояния почв равнинного Приамурья // Современные проблемы регионального развития: Материалы IV Междунар. конф. - Биробиджан, 9-12 октября 2012 г. Биробиджан: ИКАРП ДВО РАН, ДВГСГА, 2012. - С. 29-30.

13. Определение химических форм микроэлементов в биологических объектах / Н.В. Иваненко, Н.Д. Соловьев, А.А. Иваненко, Л.Н. Москвин // Аналитика и контроль. - 2012. - Т. 6. № 2. - C. 108-133.

14. Захарченко А.В., Алексеев В.И., Ипатова Д.В Иерархическая концепция неоднородности почв и планирование масштаба исследования // Известия Томского политехнического университета. Инжиниринг георесурсов. - 2016. - Т. 327. - № 4. C. $149-163$.

15. Evaluating Soil Quality Indices in an Agricultural Region of Jiangsu Province / Y. Qi, J.L. Darilek, B. Huang, Y. Zhao, W. Sun, Z. Gu // Geoderma. - 2009. - V. 149. - Iss. 3-4. - P. 325-334. URL: https://doi.org/10.1016/j.geoderma.2008.12.015 (дата обращения: 25.01.2019).

16. ГОСТ 26423-85. Почвы. Методы определения удельной электрической проводимости. $\mathrm{pH}$ и плотного остатка водной вытяжки. - М.: Изд-во стандартов, 1985. - 7 с.

17. Soil Quality: A Concept, Definition, and Framework for Evaluation (A Guest Editorial) / D.L. Karlen, M.J. Mausbach, J.W. Doran, R.G. Cline, R.F. Harris, G.E. Schuman // Soil Science Society of America Journal, 1997. - V. 61. - P. 4-10.

18. Manceau A., Marcus M., Tamura N. Quantitative speciation of heavy metals in soils and sediments by synchrotron X-ray techniques // Applications of Synchrotron Radiation in LowTemperature Geochemistry and Environmental Science. Reviews in Mineralogy and Geochemistry. Washington. DC. - 2002. V. $49 .-$ P. 341-428.

19. Влияние аэротехногенных на содержание тяжелых металлов в травянистых растениях Нижнего Дона / Т.М. Минкина, С.С. Манджиева, В.А. Чаплыгин, Г.В. Мотузова, М.В. Бурачевская, Т.В. Бауэр, С.Н. Сушкова, Д.Г. Невидомская // Почвоведение. - 2017. - № 6. - С. 759-768. D0I: 10.7868/ $80032180 \times 17060077$.

20. Brown G.E., Foster A.L., Ostergren J.D. Mineral surface and bioavailability of heavy metals: A molecular-scale perspective // Proceedings of the National Academy of Sciences of the United States of America. - 1999. - V. 96. - P. 3388-3395.

21. Оценка потенциальной пожароопасности осушенных болот Томской области / А.А. Синюткина, Е.Н. Бурнашова, А.А. Беленко, Л.П. Гашкова, А.А. Малолетко // Известия Томского политехнического университета. Инжиниринг георесурсов. 2015. - T. 326. - № 12. - C. 45-53.

22. Soil Quality in a Mediterranean Area of Southern Italy as Related to Different Land Use Types / R. Marzaioli, R. D'Ascoli, R.A. De Pascale, F.A. Rutigliano // Applied Soil Ecology. 2010. - V. 44. - P. 205-212. URL: https://doi.org/10.1016/j.apsoil.2009.12.007 (дата обращения: 25.01.2019).

23. Cao X.D. Effects of redox potential and $\mathrm{pH}$ value on the release or rare elements from soil // Chemosphere. - 2001. - V. 44. P. 655-661.

24. Soil Quality Characteristics of Kikuyu-Ryegrass Pastures in South Africa / P.A. Swanepoel, C.C. du Preez, P.R. Botha, H.A. Snyman, J. Habig // Geoderma. - 2014. - V. 232. P. 589-599. URL: https://doi.org/10.1016/j.geoderma.2014.06.018 (дата обращения: 25.01.2019).

25. A Practical Approach for Deriving All-Weather Soil Moisture Content Using Combined Satellite and Meteorological Data / P. Leng, Z.L. Li, S.B. Duan, M.F. Gao, H.Y. Huo // ISPRS Journal of Photogrammetry and Remote Sensing. - 2017. - V. 131. P. 40-51. URL: https://doi.org/10.1016/j.isprsjprs.2017.07.013 (дата обращения: 25.01.2019).

26. Mondal M.K., Bhuiyan S.I., Franco D.T. Soil Salinity Reduction and Prediction of Salt Dynamics in the Coastal Ricelands of Bangladesh // Agricultural Water Management. - 2001. - V. 47. P. 9-23.

27. Adewuyi G.O., Osobamiro M.T. Chemical speciation and potential mobility of some toxic metals in tropical agricultural soil // Research Journal of Environmental Toxicology. -2016. V. 10. - P. 159-165. DOI: 10.3923/rjet.2016.159.165

28. Shaheen S.M., Rinklebe J., Tsadilas C.D. Fractionation and mobilization of toxic elements in floodplain soils from Egypt, Germany, and Greece: a comparison study // Eurasian Soil Science. 2015. - V. 48. - № 12. - P. 1317-1328. DOI: 10.1134/ S1064229315120121.

Поступила 30.01.2019 2.

\section{Информация об авторах}

Зубарев В.A., научный сотрудник Федеральное государственное бюджетное учреждение науки Института комплексного анализа региональных проблем ДВО РАН.

Мищук C.H., кандидат экономических наук, ведущий научный сотрудник Института комплексного анализа региональных проблем ДВО РАН. 
UDK $631.4(571.621)$

\title{
CHANGES IN CONCENTRATION OF HEAVY METALS IN SOILS OF MIDDLE AMUR LOWLAND UNDER CONDITIONS OF LONG PERIOD OF AGRICULTURAL USE
}

\author{
Vitaliy A. Zubarev', \\ Zubarev_1986@mail.ru \\ Svetlana N. Mishchuk', \\ svetamic79@mail.ru
1 Institute for Complex Analysis of Regional Problems, Far Eastern Branch, Russian Academy of Sciences, 4, Sholom-Aleikhem street, Birobidzhan, 679016, Russia.

Relevance of the research is caused by the need to assess the ecological state of the restored arable soils located in the border areas of the Middle Amur Lowland. The study was conducted on the example of the Leninsky district of the Jewish Autonomous Region. Mostly in this region, Chinese farmers grow soybeans. Large number of mineral fertilizers, plant growth promoters and plant protection chemicals are used for cultivation of soybeans, which leads to degradation of agricultural soils.

The aim of the research is to analyze the changes in concentrations of heavy metals in the soils of the Middle Amur Lowland during longterm agricultural use.

Object: non-ameliorated and ameliorated meadow-gley arable soils used in agricultural land turnover.

Methods: atomic absorption spectrometry method on the «Solaar 6M» spectrometer and calculation of total soil contamination coefficients.

Results. The study showed that the change in concentrations of heavy metals of soils of the Middle Amur Lowland during prolonged agricultural use could be influenced by atmospheric moisture of the summer-autumn period. It is shown that in reclaimed soils by the end of the agricultural season there is a decrease in the content of heavy metals and in the total pollution coefficient, while in untreated soils - the opposite process - the increase in pollution. The authors have studied the influence of the extent of flooding of the floodplains on humus content and soil acidity, which determine the migration, and the formation of concentration series of heavy metals. In dry years, metal concentrations remained virtually unchanged, during the flood period (2013-2014), with heavy precipitation the processes leading to increase in concentrations of zinc, lead and copper prevailed. Flooding of soils changed the content of heavy metals due to mechanical runoff, decrease of humus content and change of soil acidity.

\section{Key words:}

Middle Amur Lowland, meadow-gley soils, heavy metals, border area, drainage melioration.

The reported study was funded by RFBR, project nomber 17-32-01100-PHS.

\section{REFERENCES}

1. Konarbaeva G.A., Yakimenko V.N. Ecological and agrochemical assessment of the content of heavy metals in soil and plants of agrocenosis. Problemy agrohimii i ehkologii, 2017, vol.1. P. 16-21. In Rus.

2. Zubarev V.A., Kogan R.M. Ecological Conditions of Watercourses in the Middle Amur Lowland in the Areas of Drainage Reclamation. Water Resources, 2017, vol. 44, no. 7, pp. 940-951. Available at: http://doi.org/10.1134/S0097807817070144 (accessed 25 January 2019).

3. Zubarev V.A. Spatial change of nutrient content in the soils of Middle Amur Lowland (1976-1991). Regional problems, 2014, vol. 17, no. 1, pp. 54-57. In Rus.

4. Zubarev V.A. Agrochemical estimation of arable lands in Jewish autonomous region for the period of 1963-1992. Regional problems, 2017, vol. 20, no. 3, pp. 68-73. In Rus.

5. Mishchuk S.N. Russian-Chinese agricultural cooperation in the Russian Far East. Regional Research of Russia, 2016, vol. 6, no. 1, pp. 59-69. In Rus. Available at: https://doi.org/10.1134/ S2079970516010093 (accessed 25 January 2019).

6. Mishchuk S.N., Komarova T.M., Moshkov A.V. Transformation of the territorial structure of economy of Jewish Autonomous Region in the post-reform period. Regional problems, 2017, vol. 20, no. 2, pp. 57-64. In Rus.

7. Burdukovskii M.L., Golov V.I., Kovshik I.G. Changes in the agrochemical properties of major arable soils in the south of the Far East of Russia under the impact of their long-term agricultural use. Eurasian Soil Science, 2016, vol. 49, no. 10, pp. 1174-1179.
In Rus. Available at: https://doi.org/10.1134/ S1064229316100057 (accessed 25 January 2019).

8. Fetisov D.M., Klimina E.M. Anthropogenic changes of geosystems on the Middle Amur Lowland: retrospective analysis. Regional problems, 2015, vol. 18, no. 4, pp. 60-65. In Rus.

9. Anoshkin A.V. Development of floodplain-channel river complexes in Jewish autonomous region during extreme floods and high water. Regional problems, 2015, vol. 18, no. 1, pp. 35-42. In Rus.

10. Roslikova V.I. Soils of the Middle-Amur Lowland and features of their agrogenic transformations. Bulletin of Pacific national university, 2009, vol. 2, no. 13, pp. 95-102. In Rus.

11. GOST 28168-89. Pochvy. Otbor prob [State standard 28168-89. Soil. Sample selection]. Moscow, Standartinform Publ., 2008. $7 \mathrm{p}$.

12. Matyushkina L.A. Problemy i printsipy ekologo-agrokhimicheskoy otsenki sostoyaniya pochv ravninnogo Priamurya [Problems and principles of ecological and agrochemical soil assessment of the plain Priamurye]. Materialy IV mezhdunarodnoy konferentsii. Souremennye problemy regionalnogo razuitiya [Modern problems of regional development. Proc. of IV International Conference]. Birobidzhan, 9-12 October 2012. Birobidzhan, IKARP DVO RAN, DVGSGA Publ., 2012. pp. 29-30.

13. Ivanenko N.V., Solovev N.D., Ivanenko A.A., Moskvin L.N. Trace element speciation analysis of biological media. Analytics and Control, 2012, vol. 6, no. 2, pp. 108-133. In Rus.

14. Zakharchenko A.V., Alekseev V.I., Ipatova D.V Hierarchical concept of soil heterogeneity and planning the scale of investiga- 
tions. Bulletin of the Tomsk Polytechnic University. Geo Assets Engineering, 2016, vol. 327, no. 4, pp. 149-163. In Rus.

15. Qi Y., Darilek J.L., Huang B., Zhao Y., Sun W., Gu Z. Evaluating Soil Quality Indices in an Agricultural Region of Jiangsu Province. Geoderma, 2009. vol. 149, no. 3-4, pp. 325-334. Available at: https://doi.org/10.1016/j.geoderma.2008.12.015 (accessed 25 January 2019).

16. GOST 26423-85. Pochvy. Metody opredeleniya udelnoy elektricheskoy provodimosti, pH i plotnogo ostatka vodnoy vytyazhki [Soils. Methods for determining the electrical conductivity, $\mathrm{pH}$ and the solid residue of the aqueous extract]. Moscow, Izdatelstvo Standartov Publ., 1985.7 p.

17. Karlen D.L., Mausbach M.J., Doran J.W., Cline R.G., Harris R.F., Schuman G.E. Soil Quality: A Concept, Definition, and Framework for Evaluation (A Guest Editorial). Soil Science Society of America Journal, 1997, vol. 61, pp. 4-10.

18. Manceau A., Marcus M., Tamura N. Quantitative speciation of heavy metals in soils and sediments by synchrotron X-ray techniques. Applications of Synchrotron Radiation in Low-Temperature Geochemistry and Environmental Science. Reviews in Mineralogy and Geochemistry. Washington, DC, 2002, vol. 49, pp. 341-428. Available at: https://doi.org/10.2138/gsrmg.49.1.341 (accessed 25 January 2019).

19. Minkina T.M., Mandzhieva S.S., Chaplygin V.A., Motuzova G.V., Burachevskaya M.V., Bauehr T.V., Sushkova S.N., Nevidomskaya D.G. Effect of aerotechnogenic emissions on the content of heavy metals in herbaceous plants of the Lower Don region. Pochvovedenie. Eurasian Soil Science, 2017, vol. 50, no. 6, pp. 746-755. DOI: 10.1134/S1064229317060072. In Rus.

20. Brown G.E., Foster A.L., Ostergren J.D. Mineral surface and bioavailability of heavy metals: A molecular-scale perspective. Proceedings of the National Academy of Sciences of the United States of America, 1999, vol. 96, pp. 3388-3395. DOI: $10.1073 /$ pnas. 96.7 .3388

21. Sinyutkina A.A., Burnashova E.N., Belenko A.A., Gashkova L.P., Maloletko A.A. Assessment of potential fire risk of
Tomsk region mires. Bulletin of the Tomsk Polytechnic University. Geo Assets Engineering, 2015, vol. 326, no. 12, pp. 45-53. In Rus.

22. Marzaioli R., D'Ascoli R., De Pascale R.A., Rutigliano F.A. Soil Quality in a Mediterranean Area of Southern Italy as Related to Different Land Use Types. Applied Soil Ecology, 2010, vol. 44, pp. 205-212. Available at: https://doi.org/10.1016/j.apsoil.2009.12.007 (accessed 25 January 2019).

23. Cao X.D. Effects of redox potential and $\mathrm{pH}$ value on the release or rare elements from soil. Chemosphere, 2001, vol. 44, pp. 655-661.

24. Swanepoel P.A., Du Preez C.C., Botha P.R., Snyman H.A., Habig J. Soil Quality Characteristics of Kikuyu-Ryegrass Pastures in South Africa. Geoderma, 2014, vol. 232, pp. 589-599. Available at: https://doi.org/10.1016/j.geoderma.2014.06.018 (accessed 25 January 2019).

25. Leng P., Li Z.L., Duan S.B., Gao M.F., Huo H.Y. A Practical Approach for Deriving All-Weather Soil Moisture Content Using Combined Satellite and Meteorological Data. ISPRS Journal of Photogrammetry and Remote Sensing, 2017, vol. 131, pp. 40-51. Available at: https://doi.org/10.1016/j.isprsjprs.2017.07.013 (accessed 25 January 2019).

26. Mondal M.K., Bhuiyan S.I., Franco D.T. Soil Salinity Reduction and Prediction of Salt Dynamics in the Coastal Ricelands of Bangladesh. Agricultural Water Management, 2001, vol. 47, no. 1, pp. 9-23. Available at: https://doi.org/10.1016/S03783774(00)00098-6 (accessed 25 January 2019).

27. Adewuyi G.0., Osobamiro M.T. Chemical speciation and potential mobility of some toxic metals in tropical agricultural soil. Research Journal of Environmental Toxicology, 2016, vol. 10, pp. 159-165. DOI: $10.3923 /$ rjet.2016.159.165

28. Shaheen S.M., Rinklebe J., Tsadilas C.D. Fractionation and mobilization of toxic elements in floodplain soils from Egypt, Germany, and Greece: a comparison study. Eurasian Soil Science, 2015, vol. 48, no. 12, pp. 1317-1328. DOI: 10.1134/S1064229315120121.

Received: 30 January 2019.

\section{Information about the authors}

Vitaliy A. Zubarev, researcher, Institute for Complex Analysis of Regional Problems, Far Eastern Branch, Russian Academy of Sciences.

Svetlana N. Mishchuk, Cand. Sc., leading researcher, Institute for Complex Analysis of Regional Problems, Far Eastern Branch, Russian Academy of Sciences. 